\title{
Comparison of Fish Supply Chain from Aquaculture and Sea Catchment Areas
}

\author{
Adi Djoko Guritno*, Megita Ryanjani Tanuputri \\ Department of Agroindustrial Technology, Faculty of Agricultural Technology, Universitas GadjahMada, Yogyakarta, Indonesia \\ Email: *adidjoko@tip-ugm.org
}

How to cite this paper: Guritno, A.D. and Tanuputri, M.R. (2017) Comparison of Fish Supply Chain from Aquaculture and Sea Catchment Areas. Journal of Service Science and Management, 10, 353-359. https://doi.org/10.4236/jssm.2017.104028

Received: June 14, 2017

Accepted: July 22, 2017

Published: July 25, 2017

Copyright $\odot 2017$ by authors and Scientific Research Publishing Inc. This work is licensed under the Creative Commons Attribution International License (CC BY 4.0).

http://creativecommons.org/licenses/by/4.0/

(c) (i) Open Access

\begin{abstract}
Currently, the fishery sector in Indonesia has become one of the potential and growing sectors. This study aims to compare the current condition of aquaculture fish supply chain and sea catchment fish supply chain and to analyze the logistics cost structure for both supply chains using Activity Based Costing. Convenience and snowball sampling were employed as the methodology, while data collection through in-depth interview on 133 respondents was undertaken in the Klaten region, Sleman region and coastal area of Java island, Indonesia. The difference on the dominant logistics cost of both supply chain indicates that different characteristics of fish may possibly result different logistics cost structure. The procurement cost dominates more than $70 \%$ of total logistics cost in the aquaculture supply chain, meanwhile transportation cost $(43.57 \%)$ is accounted for the highest portion in the sea catchment fish. Thus, the efficient supply chain should be encouraged to control the logistics cost and enhance the profit margin. The economics of scale, practice of cold chain system and appropriate transportation selection should be managed to optimize both supply chains.
\end{abstract}

\section{Keywords}

Supply Chain, Logistics Costs, Aquaculture, Sea Catchment Fish, Activity Based Costing

\section{Introduction}

Since the last few years, Indonesia's fishery sector shows a significant increase in productivity. This is followed by increasing demand for domestic fish-based products and exports. The government's campaign to support the consumption of fish-based processed products is increasingly encouraged to stimulate the economy of related society. In general, the fishery production in Indonesia is divided into fish from aquaculture and fish from sea catchment. Differences in the 
characteristics can be seen from the distribution system where aquaculture fish is mostly distributed alive, while the sea catchment fish is distributed in dead condition and requires proper quality management. In addition, the quantity of aquaculture fish production depends on the cultivation activity in the pond. Meanwhile, the quantity of sea catchment fish production is determined by external factors such as weather conditions and rampant practice of illegal fishing that harm Indonesian fishermen. Commonly, the commercial value of sea catchment fish is greater than the aquaculture fish. In the last decade, the production of fish in Indonesia tends to increase (Figure 1) where during 2004-2009 the production of sea catchment fish was more dominant than aquaculture fish in that year and then the dominance changed into aquaculture fish in the last five years.

Even though the production of both fishery commodities tends to increase year by year but currently the inappropriate distribution process still becomes an obstacle due to perishable characteristics of fish. Distribution of the fish requires cold supply chain management for reasons that perishable fish resulting in decreased quality and price [2] [3]. The distribution process of fish needs long stage in trading up to the consumer and it may affect the quality of fish product. In the cold supply chain management practices, all activities require cost for creating the conditions with most suitable temperature in the storage of fish. Costs incurred from the logistics activities have effects on the entirety profit on the supply chain. Competitive advantage, time and place utility and efficient movement to customer are the logistics which may encourage the profit enhancement [4]. Therefore, this study aims to compare the characteristics of supply chain of aquaculture fish and sea catchment fish, and to analyze the logistics cost structure in order to determine what activities should be controlled in regards to improve the efficiency of distribution.

\section{Methods}

This study focuses on the supply chain of fish in Java Island as the center of economic in Indonesia and uses convenience sampling and snowball sampling for sampling methodology. Convenience sampling was used to facilitate sampling

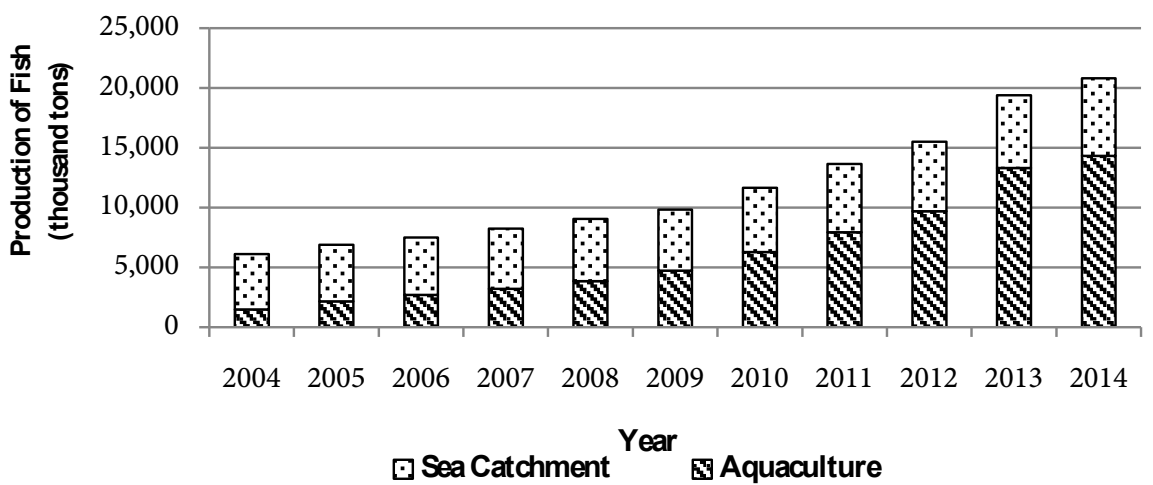

Figure 1. The production of fish in Indonesia during 2004-2014. Source: Statistics Indonesia [1]. 
at the initial supplier (fish larvae producer and fisherman), then snowball sampling was used in identifying the distribution flow to the next tier so that it can identify each tier in the whole supply chain. Snowball sampling also helps to get appropriate information based on the current condition in the field. For aquaculture fish, sampling was conducted in Special Region of Yogyakarta and its surrounding area including Sleman and Klaten region and focused on the catfish (Clarias sp.), tilapia (Oreochromisniloticus), and pomfret (Colossomamacropomum) as the fishes with the largest production in those areas. Meanwhile, convenience and snowball sampling were employed to select the fishermen and several coastal fishing ports in Java, Indonesia including in West Java, Central Java, East Java and Special Region of Yogyakarta. Mackerel tuna (Euthynnusaffinis) is the object for sea catchment fish. In-depth interview was undertaken on 69 respondents of aquaculture fish stakeholder and 64 respondents of sea catchment fish stakeholder to identify the current supply chain condition and to analyze the logistics cost incurred in both supply chain. This study determines the composition of logistics cost based on the activity involved (Activity Based Costing) including procurement, material handling, maintenance, inventory, transportation and information [5] [6] [7] as shown in the next section.

\section{Result and Discussion}

\subsection{Supply Chain Comparison}

This study was conducted to analyze the difference between the supply chain of aquaculture fish and sea catchment fish in Java Island, Indonesia. Both fishery commodities are perishable but the characteristics of both supply chain is slightly different. In-depth interview 13 fish larvae producers, 14 spreaders, 30 enlargers and 12 collectors, 22 fishermen, 22 boat owners, 8 Fish Auction Facilities, 9 traders and 11 retailers generates the information of supply chain as shown in Figure 2 and Figure 3.

Typically, both supply chains consist of six tiers but each tier has different role in each supply chain. In the supply chain of aquaculture (Figure 2), the role of

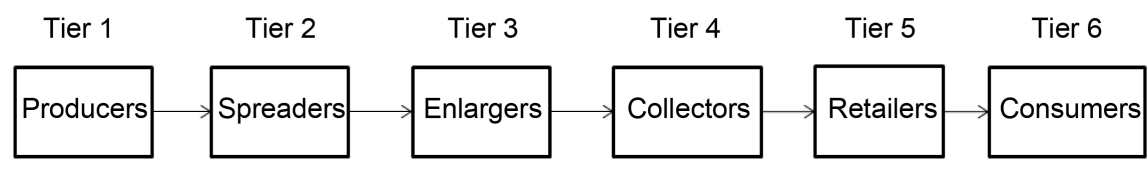

Figure 2. Supply chain of aquaculture fish.

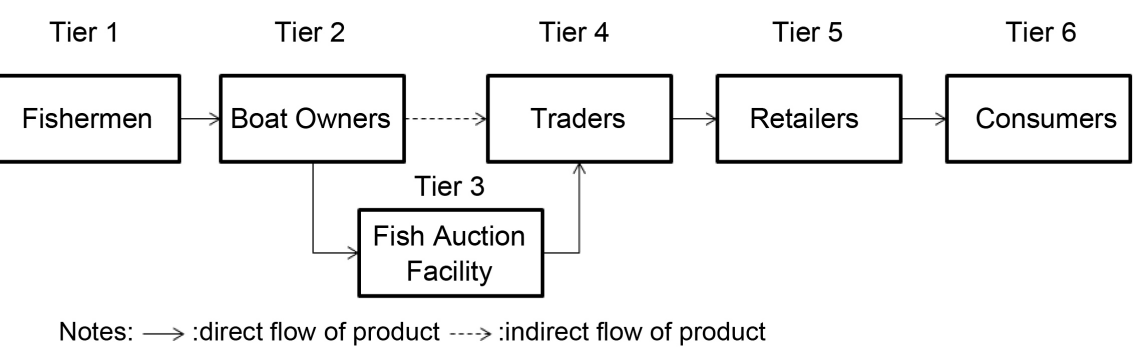

Figure 3. Supply chain of sea catchment fish. 
fish larvae producers is crucial to determine the successful of producing good egg or larvae of fish. They should pay attention on maintaining water temperature, spawning time and type of brood stock. Fish larvae then sold to the spreader for subsequent growth and continued by enlarger to enlarge the fish until the size of consumption [8]. Similar as aquaculture supply chain, fishermen as the initial supplier and tier has a crucial role on pre-fishing and post-fishing activities. Based on in-depth interview, all fishermen use boats from boat owners with the payment agreement using profit-sharing system. Those profits generate from the auction process in the Fish Auction Facility (FAF) which involving boat owners and traders. Indirect involvement of fishermen in the auction process affects the unbalance profit received by them. The role of collectors and traders in both supply chains are similar as middlemen. The role of boat owners in supply chain of sea catchment fish can be eliminated if fishermen are given direct access to communicate with traders.

In aquaculture fish, cold supply chain emphasize on the transportation activity to maintain the quality of live fish from the pond cultivated (producers) to the consumer's hands.

While on the sea catchment fish, it mainly emphasizes on keeping the quality of fresh fish that has died up to the FAF. In addition, aquaculture fish emphasizes the quality of seedlings during the initial seeding process to produce good quality of fish.

\subsection{Logistics Cost Structure Comparison}

Logistics includes the activities of goods movement within a facility, setting the incoming and outgoing shipments, and the flow of information in the supply chain [9]. Logistics cost structure analysis is completed to identify the logistics costs proportion, to analyze the most influence component costs on their respective logistics activities, and to determine which activities should be controlled and improved. In this study, comparison of logistics cost between Sleman region and Klaten region is distinguished because aquaculture fish generally sold in a fresh condition, so that differences in handling and conditions in both areas may affect the logistics costs incurred.

The calculation result of the logistics cost (Table 1) indicates a significant difference in the proportion of the cost of each logistic activity to the overall cost for aquaculture fish and sea catchment fish. Procurement activity is accounted for the highest value (IDR 10,849.70/kg and IDR 22,009.82/kg) in the logistics cost of aquaculture fish in both regions, while in the sea catchment fish, the most dominant cost is transportation cost (IDR $1727.76 / \mathrm{kg}$ ). The second highest cost in the aquaculture is material handling, while procurement cost is for sea catchment fish. Furthermore, procurement cost of aquaculture has the largest portion on the feed cost in producer, spreader and enlarger during fish cultivation. As shown in Figure 4, enlarger has the largest cost portion and most of the cost is procurement cost. Similarly, the procurement cost of sea catchment fish is wholly owned by fishermen as an initial supplier. The difference on both supply 
Table 1. The logistics cost structure comparison between aquaculture fish and sea catchment fish.

\begin{tabular}{|c|c|c|c|c|c|c|}
\hline \multirow{2}{*}{$\begin{array}{l}\text { Logistics } \\
\text { Activity }\end{array}$} & \multicolumn{2}{|c|}{$\begin{array}{l}\text { Aquaculture Fish } \\
\text { in Sleman }\end{array}$} & \multicolumn{2}{|c|}{$\begin{array}{c}\text { Aquaculture } \\
\text { Fish in Klaten* }\end{array}$} & \multicolumn{2}{|c|}{ Sea Catchment Fish } \\
\hline & $\begin{array}{l}\text { Logistics cost } \\
\left(\mathrm{IDR}^{\star *} / \mathrm{kg}\right)\end{array}$ & $\begin{array}{l}\text { Proportion } \\
\text { (\%) }\end{array}$ & $\begin{array}{c}\text { Logistics } \\
\text { cost } \\
\text { (IDR/kg) }\end{array}$ & $\begin{array}{l}\text { Proportion } \\
\text { (\%) }\end{array}$ & $\begin{array}{c}\text { Logistics } \\
\text { cost } \\
(\mathrm{IDR} / \mathrm{kg})\end{array}$ & $\begin{array}{l}\text { Proportion } \\
\text { (\%) }\end{array}$ \\
\hline Procurement & $10,849.70$ & 79.72 & $22,009.82$ & 89.00 & 1422.17 & 35.87 \\
\hline $\begin{array}{l}\text { Material } \\
\text { Handling }\end{array}$ & 1763.06 & 12.95 & 1511.59 & 6.11 & 469.02 & 11.83 \\
\hline Maintenance & 42.73 & 0.31 & 54.14 & 0.22 & 342.29 & 8.63 \\
\hline Inventory & 34.31 & 0.25 & 134.17 & 0.54 & 1.09 & 0.03 \\
\hline Transportation & 828.81 & 6.09 & 911.43 & 3.69 & 1727.76 & 43.57 \\
\hline Information & 90.57 & 0.67 & 107.62 & 0.44 & 2.87 & 0.07 \\
\hline Total & $13,609.19$ & 100.00 & $24,728.77$ & 100.00 & 3965.20 & 100.00 \\
\hline
\end{tabular}

Notes: ${ }^{*}$ excluding pomfret fish ${ }^{* *} 1$ USD $=$ IDR 13,500. Source: Based on processed data in the field, 2017.

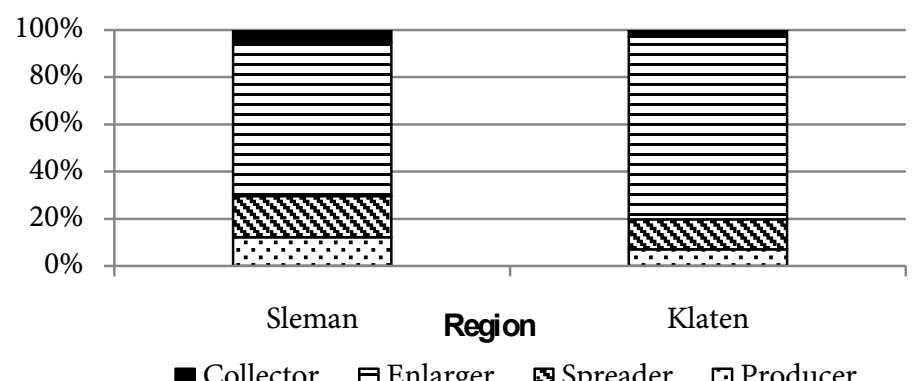

Figure 4. The proportion of each tier in the aquaculture supply chain.

chains is in the function of procurement cost where aquaculture emphasizes the addition of feed during cultivation, while another one emphasizes on the cost of supplies and cost for the captain and crew during fishing time. However, as shown in Table 2, transportation cost in the sea catchment fish is pretty higher than procurement cost and it is dominated by trader (53.53\%) and fishermen $(46.47 \%)$ due to the practice of cold chain system during delivery.

Based on the above calculation, it can be concluded that the role of fish larvae producer, spreader, enlarger and fishermen are vital because they determine the quality and quantity of fish production. Procurement activity should also be controlled due to the large portion in the whole logistics cost. Furthermore, cost efficiency should be done to encourage increasing of profit margin. Therefore, economy of scale should be considered on the aquaculture supply so that the logistics cost on the procurement activity can be minimized. The practice of cold supply chain is needed on the transportation of sea catchment fish because the fish has died up in which more perishable then the freshness. Meanwhile, the aquaculture typically sells fresh-fish so that cold chain system is not mandatory to be applied. 
Table 2. Percentage of logistics costs for each activity in sea catchment fish supply chain.

\begin{tabular}{ccccccc}
\hline Tier & $\begin{array}{c}\text { Procurement } \\
(\%)\end{array}$ & $\begin{array}{c}\text { Material } \\
\text { Handling (\%) }\end{array}$ & $\begin{array}{c}\text { Maintenance } \\
(\%)\end{array}$ & $\begin{array}{c}\text { Inventory } \\
(\%)\end{array}$ & $\begin{array}{c}\text { Transportation } \\
(\%)\end{array}$ & $\begin{array}{c}\text { Information } \\
(\%)\end{array}$ \\
\hline Fishermen & 100 & 17.29 & 91.35 & 85.50 & 46.47 & 0 \\
Boat owner & 0 & 47.12 & 0 & 0 & 0 & 12.16 \\
Trader & 0 & 35.59 & 8.65 & 14.50 & 53.53 & 87.84 \\
Total & 100 & 100 & 100 & 100 & 100 & 100 \\
\hline
\end{tabular}

Note: The highlight areas are dominant cost for each activity.

\section{Conclusion}

The result of this study indicates that the supply chain of aquaculture fish and sea catchment fish is slightly different due to the differences of characteristics. Procurement cost becomes the cost with the largest portion $(79.72 \%$ and $89.00 \%$ ) for aquaculture fish, meanwhile transportation cost (43.57\%) dominates the logistics cost on the supply chain of sea catchment fish. It is because the sea catchment fish handles the fish that has died up since fisherman's fishing time until the fish reached the hands of consumers. While in aquaculture, fish traded is fish in the fresh condition or still alive. Therefore, the economy of scale for aquaculture business is recommended to reduce the overall procurement cost, whereas in the sea catchment fish, the optimization use of cold chain system should be encouraged. On the other hand, supply chain management issues are dynamic and complex. Thus, the mixed research method and updated data are necessary to provide reliable information. The limitations in this study are the limited time of research and the lack of stakeholder knowledge in writing the organized database of logistics costs. This study currently focuses in Java Island, so it would be better if in the future research other islands are involved in better representing the condition of fish supply chain in Indonesia.

\section{Acknowledgements}

My thanks for the support given to the research fund PUPT (Penelitian Unggulan Pendidikan Tinggi) the Ministry of Research and Higher Education Indonesia. Presented as well thanks to Ms. Mutia Laraswati and Mr. Henry Putra Pradana who have helped for field survey.

\section{References}

[1] Statistics Indonesia (2017) https://www.bps.go.id/linkTabelStatis/view/id/1711

[2] Gomez-Sala, B., Herranz, C. and Hernandez, P.E. (2016) Strategies to Increase the Hygienic and Economic Value of Fresh Fish. International Journal of Food Microbiology, 223, 41-49. https://doi.org/10.1016/j.ijfoodmicro.2016.02.005

[3] Dutta, M.K., Issac, A., Minhas, N. and Sarkar, B. (2016) Image Processing Based Method to Assess Fish Quality and Freshness. Journal of Food Engineering, 177, 50-58. https://doi.org/10.1016/j.jfoodeng.2015.12.018

[4] Stock \& Lambert (2001) Strategic Logistics Management. 4th Edition, McGraw Hill, New York, 70-89. 
[5] Waters, D. (2007) Supply Chain Risk Management: Vulnerability and Resilience. The Chartered Institute of Logistics and Transportation, London, 35-50.

[6] Pishvaee, M.S., Basiri, H. and Sheikh, M.S. (2009) Supply Chain and Logistics in National, International and Governmental Environment. Springer-Verlag, Berlin, 57-83. https://doi.org/10.1007/978-3-7908-2156-7_4

[7] Ongkunaruk, P. and Piyakarn, C. (2011) Logistics Cost Structure for Mangosteen Farmers in Thailand. System Engineering Procedia, 2, 40-48. https://doi.org/10.1016/j.sepro.2011.10.006

[8] Guritno, A.D. (2016) Logistics Cost Structure Analysis for the Development of Supply Chain Strategies on Aquaculture Business. Proceeding of the Asian Business \& Management Conference (ABMC), Kobe, 11-13 October 2016, 29-34.

[9] Guritno, A.D. and Harsasi, M. (2013) Supply Chain Management. 2nd Edition, Universitas Terbuka, Yogyakarta, 2-5. (In Bahasa)

Submit or recommend next manuscript to SCIRP and we will provide best service for you:

Accepting pre-submission inquiries through Email, Facebook, LinkedIn, Twitter, etc. A wide selection of journals (inclusive of 9 subjects, more than 200 journals)

Providing 24-hour high-quality service

User-friendly online submission system

Fair and swift peer-review system

Efficient typesetting and proofreading procedure

Display of the result of downloads and visits, as well as the number of cited articles

Maximum dissemination of your research work

Submit your manuscript at: http://papersubmission.scirp.org/

Or contact jssm@scirp.org 